\title{
Is the pollination efficiency of long-lived orchid flowers affected by age? ${ }^{1}$
}

\author{
Rúbia Santos Fonseca², Flávia Aparecida dos Santos ${ }^{3}$, Milene Faria Vieira \\ http://dx.doi.org/10.1590/0034-737X201562040003
}

\begin{abstract}
The long-lived flowers of orchids increase the chances of pollination and thus the reproductive success of the species. However, a question arises: does the efficiency of pollination, expressed by fruit set, vary with the flower age? The objective of this study was to verify whether the flower age of Corymborkis flava (Sw.) Kuntze affects pollination efficiency. The following hypotheses were tested: 1) the fruit set of older flowers is lower than that of younger ones; 2) morphological observations (perianth and stigmatic area), stigma receptivity test by using a solution of hydrogen peroxide and hand-pollination tests are equally effective in defining the period of stigmatic receptivity. Flowers were found to be receptive from the first to the fourth day of anthesis. Fruit set of older flowers (third and fourth day) was lower than that of younger flowers. Morphological observations, the stigma receptivity test and hand-pollinations were equally effective in defining the period of stigmatic receptivity. However, to evaluate the maximum degree of stigma receptivity of orchid species with long-lived flowers, we recommend hand-pollinations, beyond the period of receptivity.
\end{abstract}

Key words: floral biology, fruit set, Orchidaceae, stigma receptivity.

\section{RESUMO}

\section{A eficiência da polinização em flores longevas de orquídeas é afetada pela idade da flor?}

As flores longevas das orquídeas aumentam as chances de polinização e, consequentemente, o sucesso reprodutivo. Entretanto, surge a questão: a eficiência da polinização, expressada pela produção de frutos, varia com a idade da flor? Objetivou-se verificar se a idade da flor de Corymborkis flava (Sw.) Kuntze afeta a eficiência da polinização. Foram testadas as hipóteses: 1) a frutificação em flores mais velhas é menor que em flores jovens; 2) observações morfológicas (do perianto e da área estigmática), teste de receptividade estigmática com solução de peróxido de hidrogênio e polinizações manuais são igualmente efetivos na definição do período de receptividade do estigma. A receptividade estigmática das flores foi observada do primeiro ao quarto dia de antese. A frutificação das flores mais velhas (terceiro e quarto dias) foi menor que a das jovens. As observações morfológicas, o teste de receptividade estigmática e as polinizações manuais foram igualmente efetivos na definição do período de receptividade do estigma. Porém, para as orquídeas com flores longevas são recomendadas polinizações manuais para avaliar o grau máximo de receptividade estigmática, além do período de receptividade.

Palavras-chave: biologia floral, frutificação, Orchidaceae, receptividade estigmática.

\footnotetext{
Submitted on 05/12/2014 and approved on 06/23/2015.

${ }^{1}$ This work is part of the doctoral thesis presented by the first author in the Postgraduate Program in Botany of the Universidade Federal de Viçosa.

${ }^{2}$ Universidade Estadual do Maranhão, Departamento de Química e Biologia, Caxias, Maranhão, Brazil. rubiafonseca@ hotmail.com

${ }^{3}$ Universidade Federal de Viçosa, Departamento de Biologia Vegetal, Viçosa, Minas Gerais, Brazil. flavia.aparecida@ufv.br

${ }^{4}$ Universidade Federal de Viçosa, Departamento de Biologia Vegetal, Viçosa, Minas Gerais, Brazil. mfvieira@ufv.br

*Corresponding author: rubiafonseca@ hotmail.com
} 


\section{INTRODUCTION}

Pollination is essential for the conservation and evolution of species and communities of plants (Kearns \& Inouye, 1997), ensuring the maintenance of the genetic variability in natural populations. The success of pollination is mainly influenced by three factors: the period of stigmatic receptivity, which is defined by the capacity of the stigma to ensure pollen germination; the ability of the pollen tube to grow within the style; and the viability of ovules (Sanzol \& Herrero, 2001; Dafni et al., 2005). These factors are associated with floral anthesis (Schoen \& Ashman, 1995), which is the period between flower opening and senescence, when pollinator visits occur (Primack, 1985). This period determines the flower longevity (Doorn, 1997) and, if longer than three days, the flowers are considered long-lived Primack, 1985). Orchidaceae is one of the largest families among the angiosperms and this success is based on aspects of their reproductive mechanisms, such as: diversity of floral resources, pollinators, herkogamy and floral longevity (Pijl \& Dodson, 1966; Primack, 1985; Dressler, 1993). Orchids have the longest-lived flowers, lasting up to nine months, e.g., the flowers of Grammatophyllum multiflorum Lindl. (Pijl \& Dodson, 1966). In these plants, greater longevity is observed in non-pollinated flowers; pollination promotes rapid changes that induce floral senescence (Proctor \& Harder, 1995; Martini et al., 2003; Abdala-Roberts et al., 2007). The long-lived orchid flowers have been interpreted as an adaptation to low pollinator activity (Stpiczynska, 2003), increasing the chances of pollination and thus the reproductive success (Pijl \& Dodson, 1966; Martini et al., 2003). However, a question arises: is the efficiency of pollination, expressed by fruit set, influenced by flower age? Few studies on the breeding system of orchid species provide information about the stigma receptivity during the flower lifespan. Stpiczynska (2003) examined the stigma receptivity of Platanthera chlorantha (Custer) Rchb. f. (Orchidaceae). This author found that the receptivity lasted, on average, 15 days and $89.68 \%$ of the handpollinated flowers set fruit $(83.33-100 \%)$ between the $2^{\text {nd }}$ and $19^{\text {th }}$ day of anthesis. In this case, it was found that pollination efficiency was not affected by the flower age. Most studies using hand-pollination, however, provide no information on the age of the flowers in the tests (Stort \& Galdino, 1984; Calvo, 1990; Galetto et al., 1997; Singer \& Sazima, 1999; Singer, 2001, 2002; Singer \& Sazima, 2001; Borba \& Braga, 2003; Gale, 2007; Peter \& Johnson, 2009; Micheneau et al., 2010; Srimuang et al., 2010). In studies mentioning the flower age, hand-pollinations were performed on the first
(Borba et al., 1999; Pansarin \& Amaral, 2006; Li et al., 2008; Pansarin \& Amaral, 2008; Aguiar et al. 2011) or second day of floral anthesis (Vieira et al., 2007). So far, there are no reports on the possible differences between fruit set related to the pollinated flower age. Knowledge on the optimum flower age for pollination (as expressed by maximum degree of stigma receptivity) and, consequently, the real reproductive potential of the species will enhance the efficiency of experimental pollination procedures. The purpose of this study was to verify whether the pollination efficiency of Corymborkis flava (Sw.) Kuntze, a terrestrial orchid (see Fonseca et al., 2015) of the Atlantic Forest, is affected by the flower age. The following hypotheses were tested: 1) the fruit set of older flowers is lower than that of younger ones, 2) the observation of morphological changes (stigmatic area color, presence of exudates and aspect of the perianth), stigma receptivity test by using a solution of hydrogen peroxide (for detecting the presence of stigmatic peroxidases) and hand-pollination tests are equally effective in defining the period of stigmatic receptivity.

\section{MATERIALAND METHODS}

The study was carried out at the Research, Training and Environmental Education Station "Mata do Paraíso" (RTEESMP, $20^{\circ} 45^{\prime} 07^{\prime \prime} \mathrm{S}, 42^{\circ} 55^{\prime} 31^{\prime \prime} \mathrm{W}, 690 \mathrm{~m}$ asl), the largest forest fragment (195 ha) in the municipality of Viçosa, State of Minas Gerais, southeastern Brazil. Its vegetation is part of the Atlantic Forest and, according to the classification of IBGE (2012), is a seasonal semideciduous forest. In RTEESMP, C. flava grows in areas with vegetation in an advanced stage of regeneration and occurs at a density of 600 plants/ha (personal observation). The flowering of this orchid is annual (March-June) and the flowers are long-lived, lasting for 7-9 days (Vieira et al., 2007). Its flowers are yellow, tubular (Fonseca et al., 2015), nectariferous and odorless (Vieira et al., 2007), with ornithophilous characteristics (Abreu \& Vieira, 2004). Its pollinarium consists of viscidium, caudicles and two sectile pollinia (composed of sub-units known as massulae). C. flava is self-compatible, but the occurrence of herkogamy prevents spontaneous self-pollination (more detail in Vieira et al., 2007). The period of stigma receptivity was analyzed using non-pollinated flowers $(n=25)$ at different ages. Initially, these flowers were examined with a stereomicroscope for two aspects: perianth (changes in its appearance, including the color) and stigmatic area (color and presence of exudate). Then the stigma receptivity of the same flowers was tested with $6 \%$ hydrogen peroxide (Dafni et al., 2005). Based on 
the results of the morphological observations and the stigma receptivity test, flowers $(n=40)$ with different ages were hand-pollinated (cross-pollinations) and the fruit sets were recorded. In these pollinations, the whole pollinarium, which was removed from the donnor flower on the first day of anthesis, was inserted into the stigmatic area of each receiving flower, as suggested by Dafni et al. (2005), between 11 am and 14 pm. The association between pollination success and flower age was assessed by the Trend Test $(\mathrm{A}>0$, increasing trend; $\mathrm{A}<0$, decreasing trend). The Trend test was run using BioEstat 5.0 (Ayres et al., 2007).

\section{RESULTS AND DISCUSSION}

The flowers have perianth with bright color (yellow, see Fonseca et al., 2015) and a white and moist stigmatic area until the fourth day of anthesis. On the fifth day, the perianth and the stigma become brownish, characterizing the beginning of flower senescence. The hydrogen peroxide test showed intense bubbling on the stigma of flowers from the first to the third day of anthesis. On the fourth day, there was little bubbling and on the fifth day, few bubbles were observed. The reduction in bubbling, according to Dafni \& Maués (1998), indicates a reduction in enzyme activity and, consequently, lower stigmatic receptivity. Based on these results, flowers from the first to the fourth day of anthesis were used to carry out the cross-pollinations. The fruit set data were 90 and $100 \%$ on the first and second days and 60 and $50 \%$ on the third and fourth days, respectively. It was found that the flower age influences the success of pollination, which decreases as the flower ages $(\mathrm{A}=-8$, $\left.\chi^{2}=6.8267, \mathrm{df}=1, \mathrm{p}=0.0090\right)$. During the pollination tests, differences according to the flower age were observed in the speed of pollinarium adhesion to the stigma. In the first two days, adhesion was fast, decreasing on the third day and becoming weaker on the fourth. Thus, the adherence of the pollinia in the stigmatic area can also be regarded as an indicator of stigma receptivity in C. flava. Morphological observations and the stigma receptivity test were equally effective in defining the period of stigmatic receptivity as well as handpollination. However, the highest fruit set results on the first and second day of anthesis showed that the best method to define the stigma receptivity, including its magnitude, was experimental pollination. These results provide answers to one of the purposes of studies involving stigma receptivity. Dafni et al. (2005) proposed that receptivity should be investigated in order to identify the optimum flower age for artificial pollination procedures. In orchid species, the statement that older long-lived flowers are related to lower stigma receptivity is not always true (see Stpiczynska, 2003). In addition, according to Primack (1985), the long-lived flowers of many species are not receptive throughout the entire flower lifespan, as seems to be the case of $C$. flava. Their flowers last 7-9 days (Vieira et al., 2007) and the optimum age for pollination was on the first and second days.

\section{CONCLUSIONS}

In the long-lived flowers of Corymborkis flava, morphological observations, test with hydrogen peroxide and hand-pollinations are equally effective for the definition of stigma receptivity period (four days). However, the pollination efficiency, expressed by fruit set, is affected by the flower age; the optimum age for pollination is on the first and second days. Besides this orchid, we recommend for other species with long-lived flowers, the use of hand-pollinations in receptive flowers with different ages to evaluate the maximum degree of stigmatic receptivity for a greater fruit set.

\section{ACKNOWLEDGEMENTS}

The authors thank the Fundação de Amparo à Pesquisa do Estado de Minas Gerais (FAPEMIG) and Conselho Nacional de Desenvolvimento Científico e Tecnológico (CNPq) for research grants.

\section{REFERENCES}

Abdala-Roberts L, Parra-Tabla V \& Navarro J (2007) Is floral longevity influenced by reproductive costs and pollination success in Cohniella ascendens (Orchidaceae)? Annals of Botany, 100:13671371.

Abreu CRM \& Vieira MF (2004) Os beija-flores e seus recursos florais em um fragmento florestal de Viçosa, sudeste brasileiro. Lundiana, 5:129-134.

Aguiar JMRBV, Pansarin LM, Ackerman JD \& Pansarin ER (2011) Biotic versus abiotic pollination in Oeceoclades maculata (Lindl.) Lindl. (Orchidaceae). Plant Species Biology, 27:86-95.

Ayres M, Ayres JRM, Ayres DL \& Santos AS (2007) BioEstat 5.0 Aplicações estatísticas nas áreas das ciências biológicas e médicas. Belém, Sociedade Civil Mamirauá. 364p.

Borba EL \& Braga PIS (2003) Biologia reprodutiva de Pseudolaelia corcovadensis (Orchidaceae): melitofilia e autocompatibilidade em uma Laeliinae basal. Revista Brasileira de Botânica, 26:541-549.

Borba EL, Shepherd GJ \& Semir J (1999) Reproductive systems and crossing potential in three species of Bulbophyllum (Orchidaceae) occurring in Brazilian 'campo rupestre' vegetation. Plant Systematics and Evolution, 217:205-214.

Calvo R (1990) Four year growth and reproduction of Cyclopogon cranichoides (Orchidaceae) in south Florida. American Journal of Botany, 77:736-741

Dafni A, Kevan PG \& Husbans BC (2005) Practical pollination biology. Cambridge, Enviroquest. 590p.

Dafni A \& Maués MM (1998) A rapid and simple procedure to determine stigma receptivity. Sexual Plant Reproduction, 11:117-180. 
Doorn WG van (1997) Effects of pollination on floral attraction and longevity. Journal of Experimental Botany, 48:1615-1622.

Dressler RL (1993) Phylogeny and classification of the orchid family. Portland, Dioscorides Press. 314p.

Fonseca RS, Santos FA, Menini Neto L \& Vieira MF (2015) Orchidaceae of semi-deciduous seasonal forest in Viçosa, Minas Gerais State, southeastern Brazil. Available at: <http://fieldguides.fieldmuseum.org/ guides/guide/662>. Acessed on: June 15, 2015.

Gale S (2007) Autogamous seed set in a critically endangered orchid in Japan: pollination studies for the conservation of Nervilia nipponica. Plant Systematics and Evolution, 268:59-73.

Galetto L, Bernardello G \& Rivera GL (1997) Nectar, nectaries, flower visitors, and breeding system in five terrestrial Orchidaceae from Central Argentina. Journal of Plant Research, 110:393-403.

IBGE - Instituto Brasileiro de Geografia e Estatística (2012) Manual técnico da vegetação brasileira. Rio de Janeiro, IBGE. 274p.

Kearns C \& Inouye D (1997) Pollinators, flowering plants, and conservation biology. Bioscience, 47:297-307.

Li P, Luo Y, Bernhardt P, Kou Y \& Perner H (2008) Pollination of Cypripedium plectrochilum (Orchidaceae) by Lasioglossum spp (Halictidae): the roles of generalist attractants versus restrictive floral architecture. Plant Biology, 10:220-23.

Martini P, Schlindwein C \& Montenegro A (2003) Pollination, flower longevity, and reproductive biology of Gongora quinquenervis Ruíz and Pavón (Orchidaceae) in an Atlantic Forest fragment of Pernanbuco, Brazil. Plant Biology, 5:495-503.

Micheneau C, Fournel J, Warren BH, Hugel S, Gauvin-Bialecki A, Pailler T, Strasberg D \& Chase MW (2010) Orthoptera, a new order of pollinator. Annals of Botany, 105:355-364.

Pansarin ER \& Amaral MCE (2006) Biologia reprodutiva e polinização de duas espécies de Polystachya Hook. no Sudeste do Brasil: evidência de pseudocleistogamia em Polystachyeae (Orchidaceae) Revista Brasileira de Botanica, 29:423-432.

Pansarin ER \& Amaral MCE (2008) Reproductive biology and pollination mechanisms of Epidendrum secundum (Orchidaceae). Floral variation a consequence of natural hybridization? Plant Biology, 10:211-219.

Peter CI \& Johnson SD (2009) Reproductive biology of Acrolophia cochlearis (Orchidaceae): estimating rates of cross-pollination in epidendroid orchids. Annals of Botany, 104:573-581.
Pijl L van der \& Dodson CH (1966) Orchid flowers: their pollination and evolution. Coral Gables, University of Miami Press. 214p.

Primack RB (1985) Longevity of individual flowers. Annual Review of Ecology and Systematics, 16:15-37.

Proctor HC \& Harder LD (1995) Effect of pollination success on floral longevity in the orchid Calypso bulbosa (Orchidaceae). American Journal of Botany, 82:1131-1136.

Sanzol J \& Herrero M (2001) The "effective pollination period" in fruit trees. Scientia Horticulturae, 90:01-17.

Schoen DJ \& Ashman TL (1995) The evolution of floral longevity: resource allocation to maintenance versus construction of repeated parts in modular organisms. Evolution, 49:131-139.

Singer RB (2001) Pollination biology of Habenaria parviflora (Orchidaceae: Habenariinae) in southeastern Brazil. Darwiniana, 39:201-207.

Singer RB (2002) The pollination mechanism in Trigonidium obtusum Lindl (Orchidaceae: Maxillariinae): sexual mimicry and trap-flowers. Annals of Botany, 89:157-163.

Singer RB \& Sazima M (1999) The pollination mechanism in the 'Pelexia alliance' (Orchidaceae: Spiranthinae). Botanical Journal of the Linnean Society, 131:249-262.

Singer RB \& Sazima M (2001) Flower morphology and pollination mechanism in three sympatric Goodyerinae orchids from Southeastern Brazil. Annals of Botany, 88:989-997.

Srimuang K, Watthana S, Pedersen HA, Rangsayatorn N \& Eungwanichayapant PD (2010) Flowering phenology, floral display and reproductive success in the genus Sirindhornia (Orchidaceae): a comparative study of three pollinator-rewarding species. Annales Botanici Fennici, 47:439-448.

Stort MNS \& Galdino GL (1984) Self- and cross-pollination in some species of the genus Laelia Lindl. (Orchidaceae). Revista Brasileira de Genética, 7:671-676.

Stpiczynska M (2003) Stigma receptivity during the life span of Platanthera chlorantha Custer (Rchb.) flowers. Acta Biologica Cracoviensia Series Botanica, 45:37-41.

Vieira MF, Andrade MRS, Bittencourt Jr NS \& Carvalho-Okano RM de (2007) Flowering phenology, nectary structure and breeding system in Corymborkis flava (Spiranthoideae: Tropidieae), a terrestrial orchid from a Neotropical forest. Australian Journal of Botany, 55:635-642. 